\title{
Phosphatidic acid feeding increases muscle protein synthesis and select mTORC1 pathway signaling mediators in rodent skeletal muscle
}

\author{
C Brooks Mobley ${ }^{1}$, Carlton D Fox ${ }^{1}$, Corrie Pascoe ${ }^{1}$, James Healy ${ }^{1}$, Brian S Ferguson ${ }^{1}$, Ryan P Lowery², \\ Christopher M Lockwood ${ }^{3}$, Jeffrey R Stout ${ }^{4}$, Ralf Jäger ${ }^{5}$, Andreas N Kavazis ${ }^{1}$, Jacob M Wilson², Michael D Roberts ${ }^{1^{*}}$
}

From The Eleventh International Society of Sports Nutrition (ISSN) Conference and Expo

Clearwater Beach, FL, USA. 20-21 June 2014

\section{Background}

Human and cell culture studies have demonstrated that phosphatidic acid (PA) can increase muscle mass and anabolic signaling, respectively. However, no in vivo evidence to date has examined whether PA can increase intramuscular anabolic signaling in vivo. The purpose of this study was to examine - a) if PA feeding acutely increases post-prandial muscle protein synthesis (MPS) and anabolic signaling markers; and b) if PA can enhance the post-prandial anabolic effects of whey protein concentrate (WPC).

\section{Methods}

Male Wistar rats $(\sim 250 \mathrm{~g})$ were fasted overnight $(\sim 18 \mathrm{~h})$ and fed either: a) $1 \mathrm{ml}$ water $(\mathrm{n}=14)$, b) $28 \mathrm{mg}$ PA (eq. to $1.5 \mathrm{~g}$ human dose; $\mathrm{n}=8$ ), c) $197 \mathrm{mg}$ WPC (eq. to $10 \mathrm{~g}$ human dose; $\mathrm{n}=8)$, or $\mathrm{d})$ PA+WPC $(\mathrm{n}=8) .2 .5 \mathrm{~h}$ postfeeding rats were injected with $5.44 \mathrm{mg}$ puromycin $\mathrm{diHCl}$ for MPS assessment via SUnSET and 3 hours post-feeding rats were euthanized and mixed gastrocnemius muscles were removed for immunoblotting analyses. The treatment of the animals in this study adhered to commonly accepted ethics guidelines.

\section{Results}

Compared to water-fed rats, PA feeding caused an elevation in numerous Akt-mTOR markers and, in some instances, PA+WPC exhibted a greater increase in AktmTOR signaling markers (Erk1/2 Thr202/Tyr204, Bad Ser112, p70s6k Thr389). However, compared to water-fed rats, the PA, WPC, and PA+WPC groups exhibited greater

\footnotetext{
* Correspondence: mdr0024@auburn.edu

${ }^{1}$ Auburn University, Auburn, Alabama, USA

Full list of author information is available at the end of the article
}

MPS responses with no differences existing between conditions.

\section{Conclusion}

This is the first in vivo data demonstrating that PA feeding increases MPS. More post-prandial time course data with resistance exercise is needed to better elucidate how PA feeding affects muscle anabolism.

\section{Authors' details}

'Auburn University, Auburn, Alabama, USA. ${ }^{2}$ University of Tampa, Tampa, Florida, USA. ${ }^{3} 4$ Life Research, LLC, Sandy, Utah, USA. ${ }^{4}$ University of Central Florida, Orlando, Florida, USA. ${ }^{5}$ Increnovo, LLC, Milwaukee, Wisconsin, USA.

Published: 1 December 2014

doi:10.1186/1550-2783-11-S1-P50

Cite this article as: Mobley et al:: Phosphatidic acid feeding increases muscle protein synthesis and select mTORC1 pathway signaling mediators in rodent skeletal muscle. Journal of the International Society of Sports Nutrition 2014 11(Suppl 1):P50.

Submit your next manuscript to BioMed Central and take full advantage of:

- Convenient online submission

- Thorough peer review

- No space constraints or color figure charges

- Immediate publication on acceptance

- Inclusion in PubMed, CAS, Scopus and Google Scholar

- Research which is freely available for redistribution

Submit your manuscript at www.biomedcentral.com/submit 